\title{
The Chemokine Stromal Cell-Derived Factor-1 Promotes the Survival of Embryonic Retinal Ganglion Cells
}

\author{
Sreekanth H. Chalasani, ${ }^{1}$ Frédéric Baribaud, ${ }^{2}$ Christine M. Coughlan, ${ }^{2}$ Mary J. Sunshine, ${ }^{4}$ Virginia M. Y. Lee, ${ }^{3}$ \\ Robert W. Doms, ${ }^{2}$ Dan R. Littman, ${ }^{4}$ and Jonathan A. Raper ${ }^{1}$ \\ Departments of ${ }^{1}$ Neuroscience and ${ }^{2}$ Microbiology, School of Medicine, and ${ }^{3}$ Department of Pathology and Laboratory Medicine and Center for \\ Neurodegenerative Diseases Research, University of Pennsylvania, Philadelphia, Pennsylvania 19104, and ${ }^{4}$ Howard Hughes Medical Institute, Skirball \\ Institute of Biomolecular Medicine, New York University School of Medicine, New York, New York 10016
}

The chemokine receptor CXCR4 is expressed in the embryonic and mature CNS, yet its normal physiological function in neurons remains obscure. Here, we show that its cognate chemokine, stromal cell-derived factor-1 (SDF-1), promotes the survival of cultured embryonic retinal ganglion cell neurons even in the absence of other neurotrophic factors. This survival effect is mediated primarily through a cAMP-dependent pathway that acts through protein kinase A and MAP kinase. Addition of SDF-1 to a human neuronal cell line induces phosphorylation of $\mathrm{p} 44 / \mathrm{p} 42$ MAP kinase and GSK3 $\beta$. Mouse embryos lacking the CXCR4 receptor have a reduced number of retinal ganglion cells. The ligand of CXCR4, SDF-1, may therefore provide generalized trophic support to neurons during their development and maturation.

Key words: SDF-1; slit-2; RGC; cAMP; survival; neurotrophic

\section{Introduction}

Neurons are overproduced early in development, and their excessive numbers are reduced as they compete for a limited supply of trophic factors in their environment (Hamburger and LeviMontalcini, 1949). Access to sufficient trophic support is thought to prevent the activation of an inherent suicide program common to all cells (Meyer-Franke et al., 1998; Raff, 1998; Shen et al., 1999). It has been recognized for some time that elevating intracellular levels of cAMP can promote the survival of cultured neurons (Wakade et al., 1983; Rydel and Greene, 1988; Meyer-Franke et al., 1998). The survival-promoting effect of elevating cAMP is direct in some neurons, whereas in others, it is attributable to an increased sensitivity to trophic peptides (Wakade et al., 1983; Hanson et al., 1997; Meyer-Franke et al., 1998; Rydel and Greene, 1988).

Activation of seven transmembrane G-protein-coupled receptors is one way in which an elevation of cAMP can be achieved. In this study, we explored the possibility that activating a subfamily of G-protein-coupled receptors, the chemokine receptors, promotes neuronal survival. Chemokines are relatively short peptide hormones that were originally defined as chemoat-

Received Aug. 30, 2002; revised March 7, 2003; accepted March 17, 2003.

This research was supported by National Institutes of Health Grant R01-NS26527 to J.A.R. We gratefully acknowledge Pete Bannerman and Ashleigh Hanna for help with the confocal microscope. We also thank Connie Page for providing NT2N cells, Darlene Ghavimi for making the HIV glycoproteins, Drs. Kimberly Sabelko and Andrea Webber for help with the mice, Cynthia Ito and Radhia Ben-Mohamed for technical help, and Cynthia Ito and Thomas Kreibich for their help in data analysis. We thank Dr. Morris Brinbaum and Eileen Whiteman for the GSK, phospho-GSK, and AKT antibodies; Dr. Thomas Jessell for islet-1/2 antibodies; Dr. Francis Lefcort for TrkB antibodies; and Dr. William Halfter for neurofilament antibodies. We thank Drs. David Manning and Judy Meinkoth for their advice with the signaling pathway and Li Jia, Thomas Kreibich, and Drs. Kimberly Sabelko and Andrea Webber for their help with this manuscript.

Correspondence should be addressed to Jonathan A. Raper, University of Pennsylvania School of Medicine, 1115 BRB II/III, 421 Curie Boulevard, Philadelphia, PA 19104. E-mail: raperj@mail.med.upenn.edu.

C. M. Coughlan's present address: Biological Sciences Department, 257 Crawford Hall, University of Pittsburgh, Pittsburgh, PA 15260.

Copyright $\odot 2003$ Society for Neuroscience $\quad 0270-6474 / 03 / 234601-12 \$ 15.00 / 0$ tractants for leukocytes but have since been found to have a broader spectrum of activities that includes triggering degranulation of leukocytes, cerebellar granule cell migration, angiogenesis, and T-cell differentiation (Luster, 1998; Nanki and Lipsky, 2000; Luther and Cyster, 2001; Mackay, 2001). There are $~ 50$ chemokines and 20 chemokine receptors identified to date (Luster, 1998; Murphy et al., 2000). Recently, the chemokine receptors CXCR4 and CCR5 have been shown to play an important role in the entry of HIV-1 into CD4 + T cells and macrophages (Alkhatib et al., 1996; Choe et al., 1996; Doranz et al., 1996; Dragic et al., 1996; Feng et al., 1996).

Chemokines are classified into four major families on the basis of the positions of structurally important cysteine residues. The CXC family contains the chemokine stromal cell-derived factor-1 (SDF-1), also named CXCL12 (Murphy et al., 2000). Unlike most other chemokines that activate multiple receptors, SDF-1 is thought to act exclusively through its receptor CXCR4. This is supported by the observation that both SDF-1 and CXCR4 knock-out mice die at approximately embryonic day 17 (E17) and are characterized by very similar defects in B-lymphopoiesis, myelopoiesis, cardiac ventricular septum formation, and vascular remodeling (Nagasawa et al., 1996; Ma et al., 1998; Tachibana et al., 1998; Zou et al., 1998).

CXCR4 is expressed abundantly on neurons and other cell types within the CNS (McGrath et al., 1999). Among the neural defects described in CXCR4 mutant embryos are misplaced cerebellar and dentate granule cells, leading to the suggestion that this receptor plays a role in neuronal cell migration (Zou et al., 1998; Bagri et al., 2002). Consistent with this hypothesis are the findings that SDF-1 acts as an attractant for cerebellar granule cells in vitro (Lu et al., 2001) and that ectopic expression of SDF-1 in slice cultures induces the mislocalization of migrating dentate granule neurons (Bagri et al., 2002). Our recent analysis of CXCR4 knock-outs has revealed that sensory axons expressing 
the neurotrophin receptor TrkA are misguided in the embryonic spinal cords of CXCR4 knock-outs. We have also shown recently that SDF-1 significantly reduces the responsiveness of multiple axons to several different repellent guidance cues in culture (Chalasani et al., 2003). Although these findings indicate that SDF-1 has an important role in the guidance of migrating cells and axons in the developing CNS, here, we demonstrate a very different additional function for SDF-1/CXCR4 signaling, the promotion of neuronal survival.

\section{Materials and Methods}

Cell culture and survival assay. Retinal ganglion cell (RGC) cultures were made by dissociating E6 chick neural retinas and plating them on polyL-lysine-treated laminin-coated glass coverslips at a density of 1000 neurons per well ( 48 well dish, Costar, Cambridge, MA). The medium (F-12) was supplemented with $6 \mathrm{mg} / \mathrm{ml}$ glucose, $2 \mathrm{~mm}$ glutamine, $100 \mathrm{U} / \mathrm{ml}$ penicillin, $100 \mathrm{U} / \mathrm{ml}$ streptomycin, $5 \mathrm{ng} / \mathrm{ml}$ transferrin, and $5 \mathrm{ng} / \mathrm{ml} \mathrm{se-}$ lenium along with different conditions as indicated. Chemokines were purchased from Peprotech (Rocky Hill, NJ). The cultures were fixed and stained with an antibody to islet-1 [39.4D5; Developmental Studies Hybridoma Bank (DSHB), Iowa City, IA]. Three coverslips were set up for each experiment, and 10 random fields were counted on each coverslip. The average number of islet-1-positive RGCs was compared between 72 and $24 \mathrm{hr}$. The data are the average of four experiments, with all the error bars representing an estimate of the SEM. Probability values were calculated using a two-tailed $t$ test with different variances (heteroscedastic). Human teratocarcinoma (NT2N) cells were differentiated for 5 weeks in retinoic acid to induce neuronal properties (Pleasure et al., 1992). The cells were then treated with trypsin and plated on Matrigel-coated wells in 50\% conditioned medium and 50\% DMEM with 5\% FBS, $1 \%$ penicillin-streptomycin, and the mitotic inhibitors FuDR, UR, and AraC overnight at a density of 30,000 cells per well (four-well dishes; Costar). The next day, the medium was removed, and serum-free medium with or without SDF-1 was added. These cultures were stained live using $1 \mu \mathrm{l} /$ well of Syto16 (Molecular Probes, Eugene, OR), and living cells in 50 random fields were counted. Cells were counted in two wells for each condition, and data from four independent experiments are shown.

CREB phosphorylation. Neural retinas from E6 chicks were dissociated and plated in minimal medium as described above. After $24 \mathrm{hr}$, these cultures were stimulated for $30 \mathrm{~min}$ with SDF-1 with and without $20 \mu \mathrm{M}$ AMD 3100, $100 \mathrm{ng} / \mathrm{ml}$ pertussis toxin (PTX), $200 \mathrm{~nm}$ PKI, or $20 \mu \mathrm{M}$ PD98059. The cultures were then fixed for $20 \mathrm{~min}$ with $3.7 \%$ paraformaldehyde and stained with anti-islet-1 (1:200, 39.4D5, DSHB) and antiphospho-specific CREB (ser-133, a kind gift from Dr. Judy Meinkoth). These antibodies were then detected by anti-mouse Alexa Fluor 488 and anti-rabbit Alexa Fluor 546 (Molecular Probes).

Immunohistochemistry. Frozen sections of E6 chick eyes were made at $30 \mu \mathrm{m}$ and stained with antibodies to neurofilament $(4 \mathrm{H} 6$, a gift from Dr. William Halfter, University of Pittsburgh) at 1:1000 and anti-islet-1 (39.4D5, DSHB) at 1:200. Similar sections were made of mouse embryos at E13.5 and stained with anti-neurofilament (2H3, DSHB) at 1:200 and anti-islet-1/2 (guinea pig polyclonal, a gift from Dr. Thomas Jessell, Columbia University) at 1:10,000. In the terminal deoxynucleotidyl transferase-mediated biotinylated UTP nick end labeling (TUNEL) experiment, cultures were set up with or without SDF-1 and stained for islet-1 as described along with TUNEL reagent, TMR Red (Boehringer Mannheim, Indianapolis, IN). A total of 100 islet-positive nuclei were scored for each condition, and data from four independent experiments are shown. In the bromodeoxyuridine (BrdU) experiment, cultures were set up with or without SDF-1, and BrdU at $10 \mu \mathrm{M}$ was added for $1 \mathrm{hr}$. These cultures were fixed $24 \mathrm{hr}$ later, and BrdU-positive cells were detected using an anti-BrdU antibody conjugated to fluorescein (Boehringer Mannheim). An anti-islet-1 antibody detected RGC neurons. However, no RGC neurons were found to be BrdU-positive. For the TrkB experiment, cultures were set up in the manner described above. After 24 $\mathrm{hr}$, they were left untreated or treated for $30 \mathrm{~min}$ with forskolin $(10 \mu \mathrm{m})$ or SDF-1 $(100 \mathrm{ng} / \mathrm{ml})$. All the cultures were then stained live with an antibody to TrkB (a gift from Dr. Francis Lefcort, University of Montana) at 1:1000, washed, fixed, and then processed for islet- 1 staining.

Inhibitor assays. RGC cultures were set up as described with or without SDF-1 and specific inhibitors. A protein kinase A inhibitor, PKI (Calbiochem, La Jolla, CA) at $200 \mathrm{~nm}$; a PKG inhibitor, KT5823 (Calbiochem) at $1 \mu \mathrm{M}$; a cAMP antagonist, Rp-cAMPS (Sigma, St. Louis, MO) at $20 \mu \mathrm{M}$; a cGMP antagonist, Rp-cGMPS (Sigma) at $20 \mu \mathrm{M}$; a MAP kinase inhibitor, PD98059 (Calbiochem) at $20 \mu \mathrm{M}$; a PI-3 kinase inhibitor, LY294002 (Calbiochem) at $20 \mu \mathrm{M}$; an SDF-1 antagonist, AMD3100 (AIDS Research and Reference Reagent Program, National Institutes of Health, contributed by AnorMed, Langley, British Columbia, Canada) program, 24) at $20 \mu \mathrm{M}$; CXCR4- and CCR5-tropic glycoproteins, HxB-gp120 and JRFLgp120 at $100 \mathrm{ng} / \mathrm{ml}$, and PTX (Sigma) at $100 \mathrm{ng} / \mathrm{ml}$ were used. After $48 \mathrm{hr}$, these cultures were fixed and stained for islet- 1 to identify RGCs. Data from four independent experiments are shown. The src family inhibitor PP1 was used at $1 \mu \mathrm{m}$ with or without BDNF at $100 \mathrm{ng} / \mathrm{ml}$ and SDF- 1 at $100 \mathrm{ng} / \mathrm{ml}$. Cultures were fixed at $24 \mathrm{hr}$ and another set at $72 \mathrm{hr}$, and the number of islet-1-positive cells counted in 10 random fields in each coverslip were compared. Data from four independent experiments are shown. These cultures were fixed at $48 \mathrm{hr}$, stained for islet-1, and counted in a similar manner as the rest of the inhibitor experiments. For slit-2 inhibition, protein was produced from transiently transfected 293T cells. The amount of protein was quantified by collapse assay on retinal growth cones. Equivalent volumes of slit- 2 and mock-transfected supernatants were added to the cultures at the same time as SDF-1. These cultures were also processed in a similar manner as the rest of the inhibitor experiments.

$R G C$ counts in mice. Cryostat sections $(30 \mu \mathrm{m})$ from wild-type and CXCR4 mutant E13.5 embryos were stained with islet-1 antibodies (guinea-pig polyclonal, a kind gift from Dr. Thomas Jessell). A single 2 $\mu \mathrm{m}$ optical section was reconstructed in every second $30 \mu \mathrm{m}$ section for the whole eye with images obtained with a Leica confocal microscope (Leica, Nussloch, Germany). All islet-1-positive cells were counted in each optical section in which the lumen of the eye could be visualized. The number of sections in the table represents the number of alternate sections that were counted for each eye. The nonparametric MannWhitney test was used to test the hypothesis that sampled RGC counts from wild-type and mutant eyes were no different within litters.

RNA probes and in situ hybridization. Probes of length 1300, 1200, and 300 bp, representing the entire coding sequences of the chick CXCR4, mouse CXCR4, and mouse SDF-1, were made and used on frozen sections of E6 chick and E13.5 mouse embryos. The expression was detected using an anti-DIG-AP (Boehringer Mannheim). Representative sections of expression are shown. After the sections were developed for in situ hybridization, they were then processed for islet- 1 expression to stain all of the RGC neurons.

Western blots. Cell lysates were made from NT2N cells that were plated at a density of 100,000 cells per well, serum starved for $6 \mathrm{hr}$, and treated with or without SDF-1 and the inhibitors for $20 \mathrm{~min}$. Proteins were separated on $10 \%$ Bis-Tris Nupage gels (Invitrogen, San Diego, CA) and transferred to Immobilon-P membranes (Millipore, Molsheim, France). These were then probed with antibodies to phospho-GSK3 $\beta$ (New England Biolabs, Beverly, MA), stripped in $62.5 \mathrm{~mm}$ Tris at a $\mathrm{pH}$ of 6.7 with $100 \mu \mathrm{M} \beta \mathrm{ME}$ and $2 \%$ SDS for $30 \mathrm{~min}$ at $60^{\circ} \mathrm{C}$, and then reprobed with anti-GSK3 $\beta$ (Transduction Laboratories, Lexington, KY). Alternatively, blots were probed with antibodies to phospho-MAP kinase p44/42 (New England Biolabs) and then stripped and reprobed with anti-MAP kinase p44/42 (Santa Cruz Biotechnology, Santa Cruz, CA). A composite from two separate blots is shown in the figure. These results were confirmed with multiple blots.

\section{Results \\ SDF-1 promotes the survival of cultured embryonic retinal ganglion neurons}

RGCs provide a convenient model system in which to study neuronal survival. RGC neurons can be identified in cultures of dissociated E6 chick retinas by their expression of the transcription factor islet-1 (Fig. 1B,C) (Ericson et al., 1992; Halfter, 1998). RGCs die over the course of several days when cultured in serum- 
A
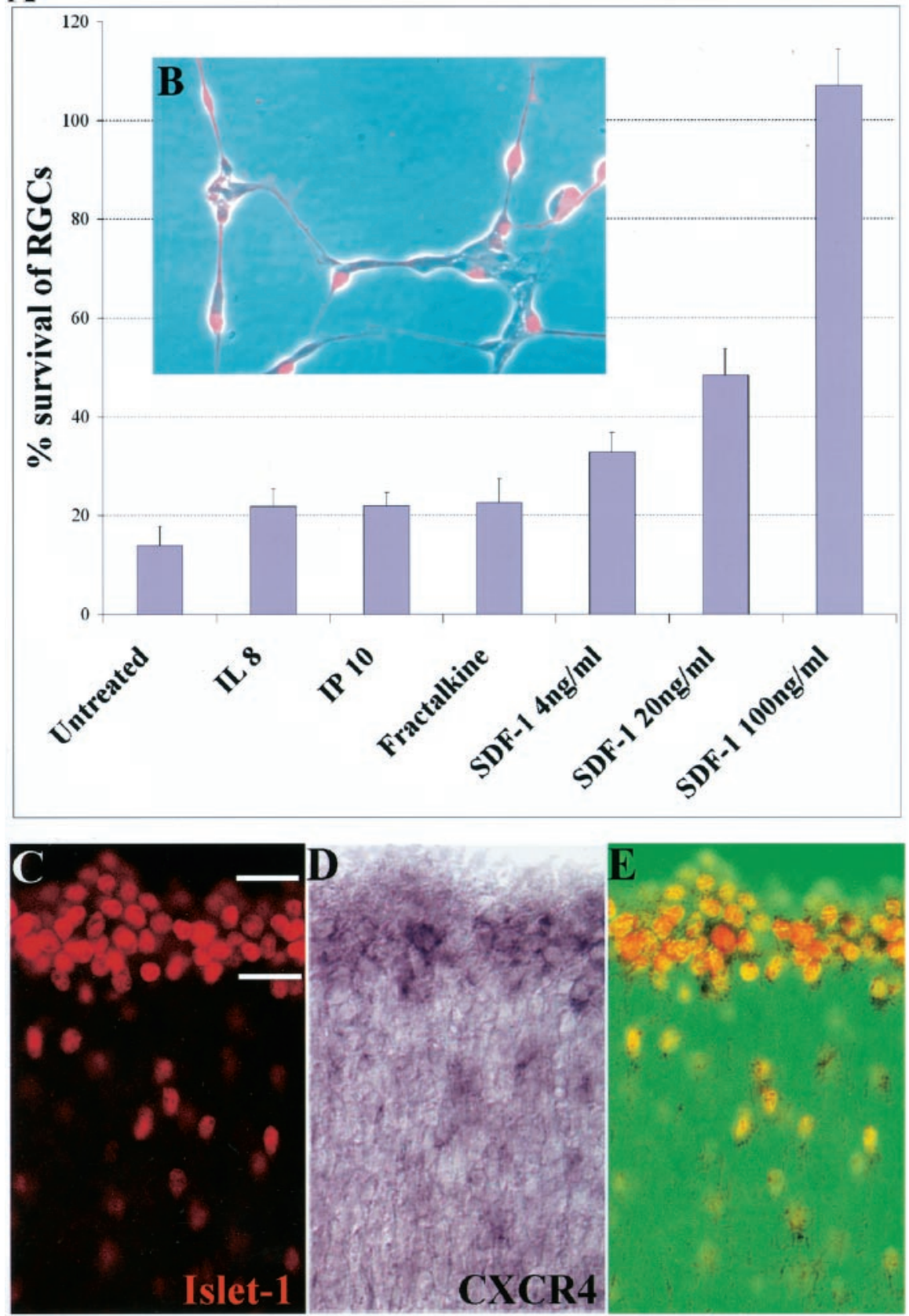

Figure 1. SDF-1 promotes the survival of cultured embryonic chick RGCs, and its receptor CXCR4 is expressed in the embryonic retina. $A$, SDF-1 promotes the survival of RGCs in a dose-dependent manner. Shown are the percentages of surviving RGCS at 72 compared with $24 \mathrm{hr}$ in the presence of $100 \mathrm{ng} / \mathrm{ml}$ selected chemokines or of $4(p=0.028), 20(p=0.008)$, or $100 \mathrm{ng} / \mathrm{ml}(p=$ $0.001)$ SDF-1. $p$ values were calculated by comparing each population with the untreated one using a two-tailed test with different variances. B, Identification of RGCs in culture with anti-islet-1. C, Visualization of RGC neurons with an antibody to islet-1 in a cross section of an E6 chick embry0. The hash marks represent the ganglion cell layer. D, Visualization of CXCR4-expressing cells in the RGC layer of this same section by in situ hybridization. E, Merged image showing CXCR4 in all islet-1-positive cells.

Figure $1 A$ shows the survival of RGC neurons plated on poly-L-lysine-treated laminin-coated glass coverslips and cultured in defined medium along with representative CXC class chemokines. Fractalkine, a member of the CX3C family, was also tested because it has been reported to rescue cultured hippocampal neurons damaged by exposure to the HIV-1 envelope protein gp120 (Meucci et al., 2000). For this, $100 \mathrm{ng} / \mathrm{ml} \mathrm{SDF-1}$ (CXCL12), interleukin-8 (IL-8; CXCL8), MIP-3 $\alpha$ (CCL20), eotaxin-1 (CCL11), RANTES (CCL5), GRO $\alpha$ (CXCL1), Fractalkine (CX3CL1), IP-10 (CXCL10), or MIP-1 $\beta$ (CCL4) was added to these cultures. The four chemokines for which data are shown act through different receptors: IL-8 via CXCR1 and CXCR2, IP-10 via CXCR3, Fractalkine via $\mathrm{CX}_{3} \mathrm{CR} 1$, and SDF-1 via CXCR4. The percentage of RGCs surviving at $72 \mathrm{hr}$ compared with those present at $24 \mathrm{hr}$ is shown. Less than $20 \%$ of the RGCs present at 24 hr survive for $72 \mathrm{hr}$ without any added chemokine. IL-8, IP-10, and Fractalkine exhibit little survival-promoting activity. In contrast, SDF-1 dramatically enhances neuronal survival, rescuing essentially all RGCs cultured under these conditions. Additional experiments demonstrated that SDF-1 also enhances the survival of cultured E8 chick sympathetic neurons (data not shown). The survival-promoting effect of SDF-1 is dose dependent in RGCs with a half-maximal effective concentration of $\sim 20 \mathrm{ng} / \mathrm{ml}$. This concentration is similar to that needed to induce chemotaxis of activated T cells and also comparable with the measured $K_{\mathrm{d}}$ for the interaction of SDF-1 with the CXCR4 receptor (Hesselgesser et al., 1998b).

The known biological effects of SDF-1 are mediated through the activation of its receptor CXCR4 (Bleul et al., 1996; Feng et al., 1996). To determine whether CXCR4 is expressed in RGC neurons, we first cloned chick CXCR4 from a chick brain cDNA library using a mouse probe from a region of the receptor that is highly conserved among different species. The coding sequence we obtained is an exact match with the recent GenBank accession number AAG09054. This sequence was

free medium without added neurotrophic factors. The adenylate cyclase activator forskolin promotes their survival, suggesting that signaling molecules that induce an elevation of cAMP could act as survival factors (Meyer-Franke et al., 1998; Shen et al., 1999) (see Fig. 3A, below). To test whether chemokines and their G-protein-coupled receptors might elevate cyclic nucleotide levels and thereby prevent neuronal death, we assayed a broad spectrum of chemokines for their ability to enhance RGC survival. Of those tested, only SDF-1 has a strong survival-enhancing effect. used to make a probe complementary to the full coding sequence of CXCR4 mRNA. Hybridization with this probe demonstrates that CXCR4 is expressed strongly within the RGC layer of E6 embryonic chick retinas (Fig. 1D). Immunohistochemical analysis revealed that all islet-positive cells in the retina express CXCR4 (Fig. 1E). Thus, RGC neurons express the receptor through which SDF-1 acts in other systems. As shown below, an antagonist of SDF-1 binding to CXCR4 interferes with the survival-enhancing effect of SDF-1. These results are consistent 
with CXCR4 serving as the SDF-1 receptor that promotes survival activity.

\section{SDF-1 reduces the number of} TUNEL-positive RGCs

The ability of SDF-1 to promote the survival of RGCs in culture could in principle be ascribed to the maintenance of already existing RGCs or to the enhanced proliferation or differentiation of progenitors that replace RGCs that die in culture. To distinguish between these two possibilities, we first determined whether SDF-1 reduces the rate of RGC death as determined by TUNEL staining (Fig. 2). As shown in Figure $2 C$, threefold fewer islet1-expressing RGCs are TUNEL-positive when cultured with SDF-1 (Fig. 2C), suggesting that SDF-1 helps prevent or delay RGC death. To determine whether SDF-1 could also act as a mitogen that helps replenish dying RGCs from a pool of progenitors, SDF-1-treated cultures were pulsed with BrdU to detect dividing cells. BrdU at $10 \mu \mathrm{M}$ was added for $1 \mathrm{hr}$ to RGC cultures with or without SDF-1; $24 \mathrm{hr}$ later, these cultures were fixed and processed to detect BrdU-labeled cells. No dividing cells were detected in our chick retinal cultures even in the presence of SDF-1. BrdU-labeled cells were easily detected in dividing cell lines cultured and processed in parallel (data not shown). We conclude that SDF-1 prevents or delays the death of already existing RGCs in culture.

\section{Enhancement of RGC survival by SDF-1 does not depend on other neurotrophins}

Previous work has shown that increasing cAMP levels with forskolin in cultured postnatal day 8 (P8) rat RGCs has only a small direct effect on their survival. Instead, elevated cAMP induces existing Trk receptors to move to the cell surface, thereby rendering RGCs more responsive to neurotrophins (Meyer-Franke et al., 1998; Shen et al., 1999). In contrast, our results indicate that SDF-1 promotes robust survival of embryonic chick RGCs even in defined medium that contains no neurotrophins (Figs. 1A, 3A). Nevertheless, because forskolin treatment promotes the survival of RGCs to the same degree as SDF-1 (Fig. 3A), we addressed the question of whether SDF-1 activates Trk receptors even in the absence of neurotrophins (Lee and Chao, 2001). The src family inhibitor PP1 was tested for its ability to block the trophic effect of SDF-1. This inhibitor reduces baseline RGC survival at all time points in our assays and effectively blocks the survival effects of BDNF. However, PP1 has no effect on SDF-1-induced survival (Fig. $3 B$ ). We next examined cell surface expression of TrkB receptors in response to SDF-1. Although elevating cAMP levels with forskolin induces a dramatic translocation of TrkB to the surfaces of chick RGCs (Fig. 3D1,D2), no such translocation of TrkB is induced by SDF-1 (Fig. 3E1,E2). This implies that the two treatments are not identical. Perhaps forskolin elevates cAMP to a different degree than SDF-1, or perhaps SDF-1 activates additional parallel signaling pathways that are unaffected by forskolin. In either case, these results imply that SDF-1 promotes the survival of embryonic chick RGCs through a mechanism that is independent of TrkB redistribution or activation.
B

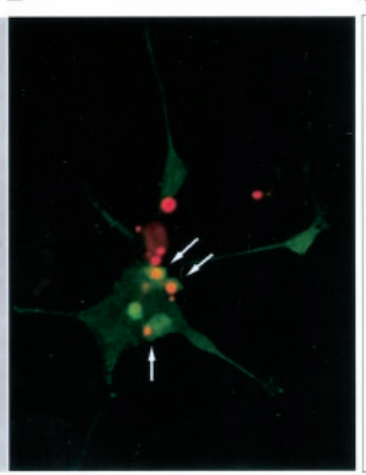

C

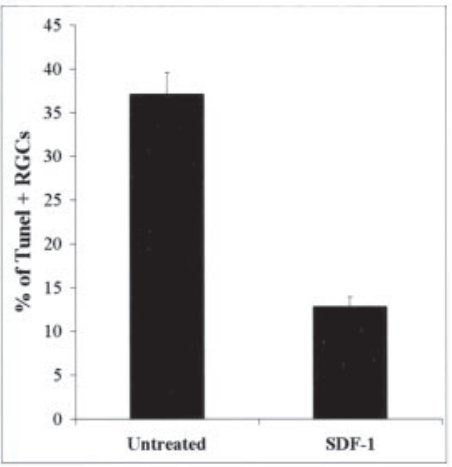

Figure 2. SDF-1 reduces the percentage of TUNEL-positive RGCs. Dissociated E6 chick neural retinas were cultured for $48 \mathrm{hr}$ population with the untreated one using a two-tailed test with different variances. Approximately threefold more TUNEL-positive RGCS were detected in the absence than in the presence of SDF-1.

\section{Enhancement of RGC survival by SDF-1 is mediated by the CXCR4 receptor}

Selected inhibitors were used to begin characterizing the signaling pathway through which SDF-1 promotes RGC survival. We allowed cultures with or without SDF-1 and a variety of specific inhibitors to grow for $48 \mathrm{hr}$. In the absence of SDF-1, $50 \%$ of RGCs die, whereas death is negligible in its presence. The survival-promoting effects of SDF-1 are reduced by the small molecule CXCR4 specific antagonist AMD3100 (Gerlach et al., 2001) (Fig. 4A, compare columns 4 and 5). This, coupled with the expression of CXCR4 on RGCs (Fig. 1E), indicates that the survival-promoting activity of SDF-1 is mediated via CXCR4. Because CXCR4 is a seven-transmembrane G-protein-coupled receptor, PTX was used to test whether the survival effects of SDF-1 require a $G_{i} / G_{o}$-type intermediary. We found that PTX blocks the survival-promoting effects of SDF-1 (Fig. 4A, compare columns 4 and 6). The HIV envelope (Env) glycoprotein HxBgp120 has been reported to have toxic effects on cultured neurons and NT2N cells, although the mechanisms by which this occurs are not clear (Hesselgesser et al., 1997, 1998a; Kaul and Lipton, 1999). Hxb-gp120 can displace SDF-1 from the CXCR4 receptor (Staudinger et al., 2001). JRFL-gp120 is another HIV Env protein that binds CCR5 instead of CXCR4 and does not affect SDF-1 binding to CXCR4 (Berger et al., 1999). Purified HxB-gp120 but not JRFL-gp120 reduced the survival-promoting activity of SDF-1 (Fig. 4B, compare columns 4-6). Neither HxB-gp120 nor JRFL-gp120 has any detectable toxic activities of its own in this assay (Fig. 4 B, compare columns 1-3). These results confirm that SDF-1 acts through CXCR4 to mediate its survival-promoting activity and also suggest that HxB-gp120-induced toxic effects could sometimes arise by its ability to block SDF-1-mediated neurotrophic action.

\section{Enhancement of RGC survival by SDF-1 is mediated by a cAMP-dependent pathway}

The survival-promoting effect of SDF-1 is completely blocked by an antagonist of cAMP, Rp-cAMPS (Fig. 4C, compare columns 4 and 5 ) and an inhibitor of PKA, PKI (Fig. 4D, compare columns 4 and 5). An antagonist of cGMP, Rp-cGMPS (Fig. 4C, compare columns 4 and 6) or an inhibitor of PKG, KT58230 (Fig. 4D, compare columns 4 and 6) only partially reduced the effective- 
$\mathbf{A}$

\section{B}
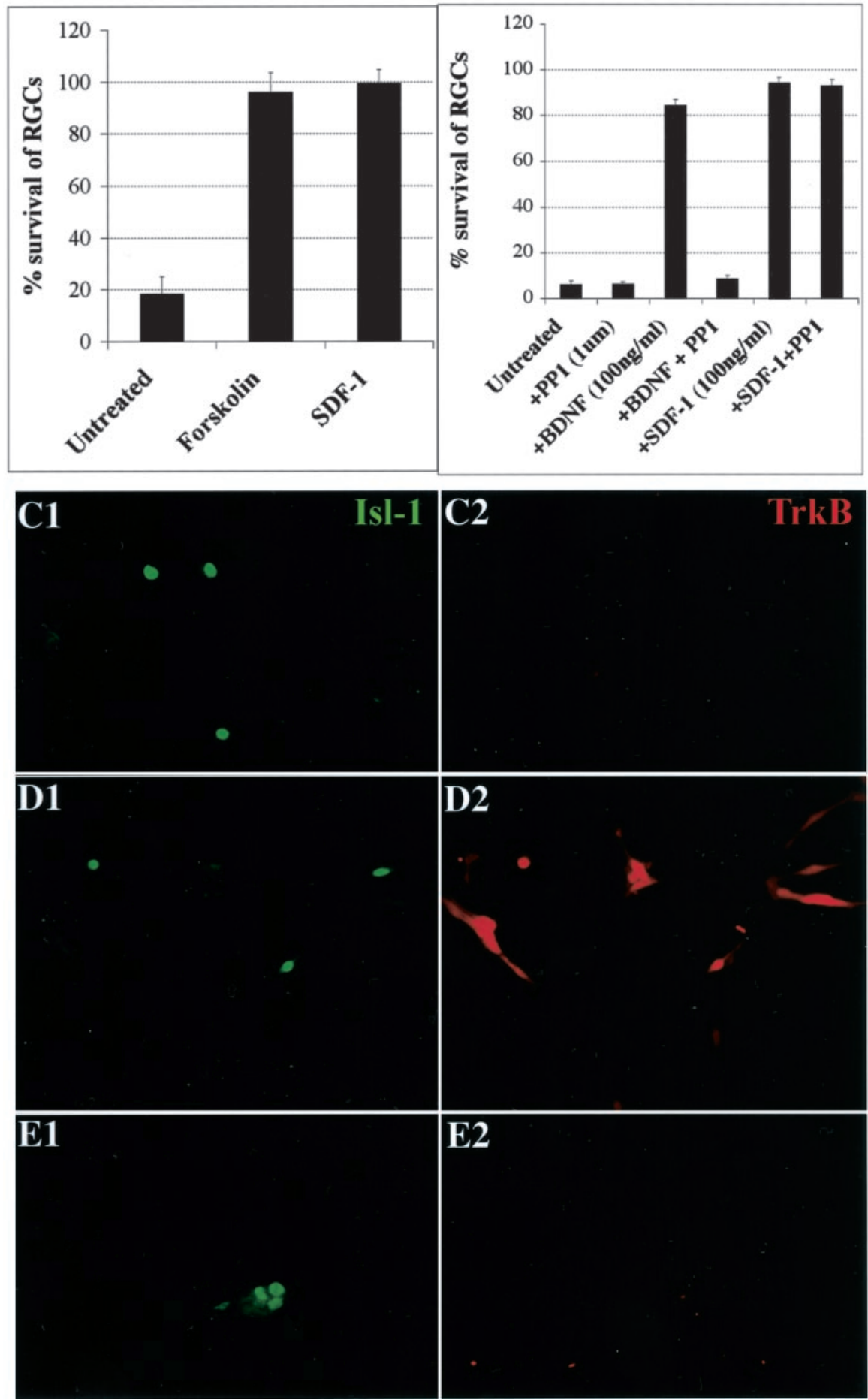

Figure 3. SDF promotes the survival of cultured $\mathrm{RGCS}$ without promoting the translocation of TrkB to the cell surface. $A, \mathrm{RGC}$ survival is enhanced by $10 \mu \mathrm{m}$ forskolin ( $p=0.002$ ) to the same degree as by $100 \mathrm{ng} / \mathrm{ml} \mathrm{SDF-1}(p=0.001$ ). The average percentages of surviving RGCs at $72 \mathrm{hr}$ compared with $24 \mathrm{hr}$ are shown for three independent experiments. $p$ values were calculated by comparing each population with the untreated one using a two-tailed test with different variances. $B$, SDF-1-promoted survival is not affected by the src family inhibitor PP1, whereas BDNF survival is completely blocked. C-E, Forskolin but not SDF-1 induces the translocation of TrkB to the surface of RGCs. After $24 \mathrm{hr}$, cultures were left untreated (C1, C2) or treated for 30 min with $10 \mu \mathrm{M}$ forskolin (D1, D2) or $100 \mathrm{ng} / \mathrm{mISDF-1} \mathrm{(E1,E2).} \mathrm{All} \mathrm{cultures} \mathrm{were} \mathrm{then} \mathrm{stained} \mathrm{live} \mathrm{with} \mathrm{anti-rabbit} \mathrm{TrkB} \mathrm{antibody.} \mathrm{RGCs} \mathrm{are} \mathrm{visualized}$ in green with anti-islet-1 (C1-E1), and surface TrkB is visualized in the same fields in red (C2-E2) (20X). Although both forskolin and SDF-1 promote the survival of RGCs, forskolin induces the translocation of TrkB to the surface of retinal cells, whereas SDF-1 does not. ness of SDF-1. A MAP kinase inhibitor, PD98059 (Fig. 4 E, compare columns 4 and 5) significantly reduces the SDF-1-induced survival effect, whereas a PI3 kinase inhibitor, LY 294002, (Fig. 4E, compare columns 4 and 6) does not. None of these agents affected RGC survival in the absence of SDF-1, indicating that nonspecific and toxic effects of these agents are minimal as used. These results are consistent with the hypothesis that SDF-1 induces most of its survival-enhancing effects in RGC neurons by binding to the CXCR4 receptor and that activation of the receptor stimulates a cAMP-mediated signaling cascade ultimately promoting RGC survival.

\section{SDF-1 induces the phosphorylation of CREB}

A convenient readout for the elevation of cAMP is cAMP-stimulated phosphorylation of CREB and the translocation of phospho-CREB from the cytoplasm into nuclei (Gonzalez and Montminy, 1989; Hagiwara et al., 1993). An antibody specific to the phosphorylated form can identify activated CREB. Retinal neurons were plated in fully defined minimal medium for $24 \mathrm{hr}$. RGC neurons were identified by staining with an islet-1 antibody. There is almost no phosphorylated CREB in RGC nuclei under these baseline conditions (Fig. 5, compare $A 1$ and $A 2$ ). In contrast, phospho-CREB is clearly detected in RGC nuclei after exposure to $100 \mathrm{ng} / \mathrm{ml}$ SDF-1 for $30 \mathrm{~min}$ (Fig. 5, compare B1 and B2). SDF-1-dependent phosphorylation of CREB is blocked by the SDF-1 antagonist AMD3100 (Fig. 5, compare C1 and C2), the $\mathrm{G}_{\mathrm{i}} / \mathrm{G}_{\mathrm{o}}$ inhibitor PTX (Fig. 5, compare D1 and D2) and the PKA inhibitor PKI (Fig. 5, compare E1 and E2). In some instances, CREB can be activated in a PKAindependent manner via MAP kinase (Grewal et al., 2000). The MAP kinase inhibitor PD98059 does not block SDF-1-induced CREB phosphorylation in RGCs (Fig. 5, compare F1 and F2), although it can block SDF-1-mediated cell survival (Fig. $4 E$ ), indicating that this alternative pathway for CREB activation is not activated by SDF-1. These results support a pathway in which SDF-1 activates its receptor CXCR4, acts through a $G_{i} / G_{o}$ intermediary, and induces an elevation in CAMP.

\section{Enhancement of NT2N survival by SDF-1 is associated with phosphorylation of MAP kinase and GSK3b}

To better define the signaling pathway through which SDF-1 promotes neuronal survival, it was necessary to identify a neu- 

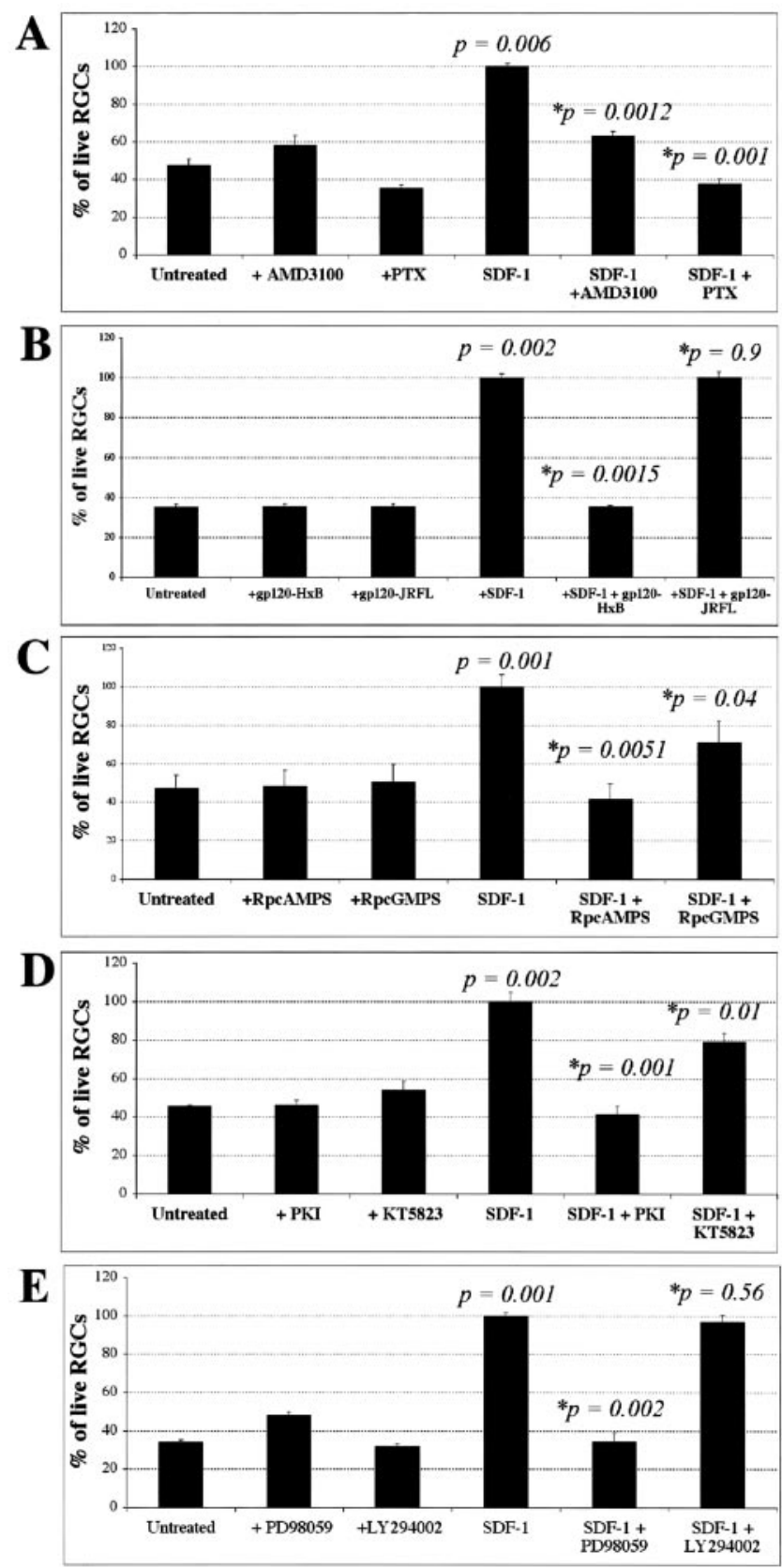

Figure 4. Signaling pathways required for SDF-1-mediated RGC survival. The average number of RGCs per field $48 \mathrm{hr}$ after plating is shown for each condition in four independent experiments. Each inhibitor was tested in the presence or absence of $100 \mathrm{ng} / \mathrm{ml} \mathrm{SDF-1.} \mathrm{A,} \mathrm{AMD3100}$ $(20 \mu \mathrm{M})$, an antagonist of SDF-1 binding to $\mathrm{XXCR4}$, does not affect RGC survival by itself but blocks the survival-enhancing effect of SDF-1. The $G_{i}$ inhibitor PTX ( $\left.100 \mathrm{ng} / \mathrm{ml}\right)$ does not affect RGC survival by itself but blocks the survival-enhancing effect of SDF-1. B, HxB-gp120 (100 $\mathrm{ng} / \mathrm{ml}$ ), an antagonist of SDF- 1 binding to $C X C R 4$, does not affect RGC survival by itself but blocks the survival-enhancing effect of SDF-1. JRFL-gp120 (100 ng/ml) does not antagonize SDF-1 binding and does not block its survival effect $C$, The CAMP antagonist Rp-cAMPS $(20 \mu \mathrm{M})$ does not affect RGC survival by itself but blocks the survival-enhancing effect of SDF-1. The CGMP antagonist Rp-CGMPs $(20 \mu \mathrm{M})$ has a lesser effect on SDF-1 activity than the CAMP antagonist. D, The PKA inhibitor PKI (200 nm) does not affect RGC survival by itself but blocks the survivalenhancing effect of SDF-1, whereas a $1 \mu \mathrm{m}$ concentration of the PKG inhibitor KT5823 is less effective in blocking the effect of SDF-1.E, The survival effect of SDF- 1 is also blocked by a $20 \mu \mathrm{m}$ concentration of the MAP kinase inhibitor PD98059. In contrast, a $20 \mu \mathrm{m}$ concentration of the PI-3 kinase inhibitor LY294002 does not reduce the effect of SDF-1. $p$ values were calculated by comparing each population with the untreated one, and those with an asterisk were obtained comparing each population with the SDF-1-treated one using a two-tailed test with different variances. ronal cell line whose survival is similarly enhanced. NT2 neurons $(\mathrm{NT} 2 \mathrm{~N})$ are differentiated teratocarcinoma cells that have neuronal properties that include axonal and dendritic process outgrowth, synapse formation, and the ability to integrate into neural tissues in vivo (Pleasure et al., 1992; Hartley et al., 1999; Philips et al., 1999). NT2N cells have also been shown to express CXCR4 and respond to SDF-1 by activating strong calcium transients (Coughlan et al., 2000). When cultured in serum-free medium, they begin to die within the first day of culture. Very high concentrations of SDF-1 have been reported to induce cell death in NT2N cells (Hesselgesser et al., 1998a). In contrast, we find that lower concentrations of SDF-1 promote NT2N survival. Roughly $40 \%$ of NT2N cells die during a $24 \mathrm{hr}$ time period, but many of these dying cells are rescued by SDF-1 (Fig. 6A). To investigate the signaling pathway affected by SDF-1, Western blots of NT2N cell lysates were made from cultures without SDF-1, with SDF-1, and with SDF-1 plus selected inhibitors. These blots were then probed for the phosphorylated and nonphosphorylated forms of two kinases reported to be in the downstream pathway of CXCR4 activation: Akt and MAP kinase p44/42 (Ganju et al., 1998). The phosphorylation of GSK $3 \beta$ was also monitored because both it and MAP kinase have been reported to be activated by forskolin and have been proposed to promote cell survival in other systems. Although GSK $3 \beta$ is normally considered a downstream effector of Akt, MAP kinase has also been reported to directly phosphorylate GSK3 $\beta$ in cortical neurons (Li et al., 2000).

SDF- 1 induces the phosphorylation of both GSK $3 \beta$ and MAP kinase (Fig. 6B, compare columns 1 and 2 in rows 1 and 3), consistent with the ability of the MAP kinase inhibitor PD98059 to block the SDF survival effect (Fig. $4 E$ ). Indeed, phosphorylation of both MAP kinase and GSK $3 \beta$ was greatly inhibited by the same inhibitors of PKA and MAP kinase that blocked the survival-promoting effects of SDF-1 on chick RGCs (Fig. $6 B$, compare column 1 with columns 3 and 4 in rows 1 and 3 ). No phosphorylation of Akt was detected on our blots (data not shown). MAP kinase appears to be upstream from GSK3 $\beta$, because inhibiting MAP kinase activity prevents SDF-1 from inducing GSK3 $\beta$ phosphorylation. A PKG inhibitor did not block phosphorylation of either MAP kinase or GSK3 $\beta$ (Fig. $6 \mathrm{~B}$, compare columns 1 and 5 in rows 1 and 3 ). These results support the hypothesis that SDF-1 activates a cAMP-triggered signaling cascade that promotes neuronal survival through MAP kinase and GSK3 $\beta$. Under similar conditions, however, we were unable to detect a significant increase in cAMP levels using a radioimmunoassay in NT2N cells treated with SDF-1. The CXCR4-tropic glycoprotein HxB-gp120 prevents SDF-1-induced phosphorylation of MAP kinase and GSK3 $\beta$ in NT2N cells, whereas the CCR5-tropic glycoprotein JRFL-gp120 had no such effect (Fig. $6 C$, compare column 1 with columns 5 and 6 in rows 1 and 3 ). Neither of the two glycoproteins alone have any effect on the phosphorylation of either GSK $3 \beta$ or MAP kinase (Fig. $6 C$, compare column 1 with columns 3 and 4 in rows 1 and 3 ). These results are consistent with the idea that Hxb-gp120 blocks SDF-1 neurotrophic effects by preventing SDF-1 from binding and activating CXCR4.

\section{SDF-1-induced survival can be blocked by slit-2}

We then analyzed the effects of another molecule, slit-2, on SDF1 -induced RGC survival. Slit-2 was originally described in vertebrates as a branching factor, promoting branching of DRG axons, and a chemorepellent for migrating cells in the CNS (Wang et al., 1996; Hu, 1999). Since then, it has been shown to repel a variety of axons, including retinal axons, olfactory bulb axons, and fore- 

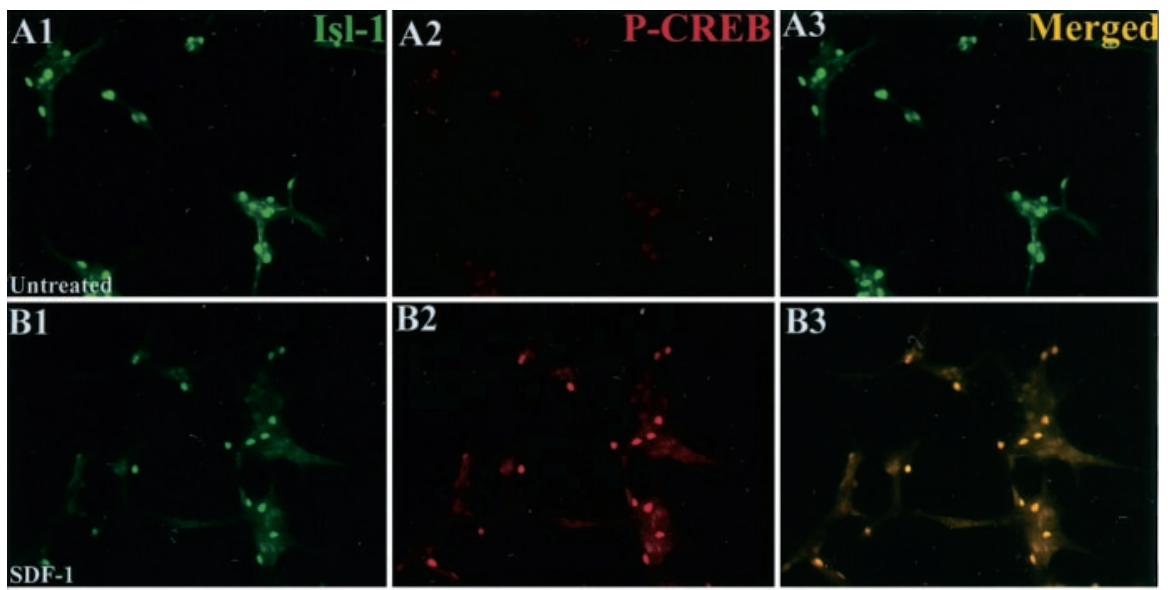

B3
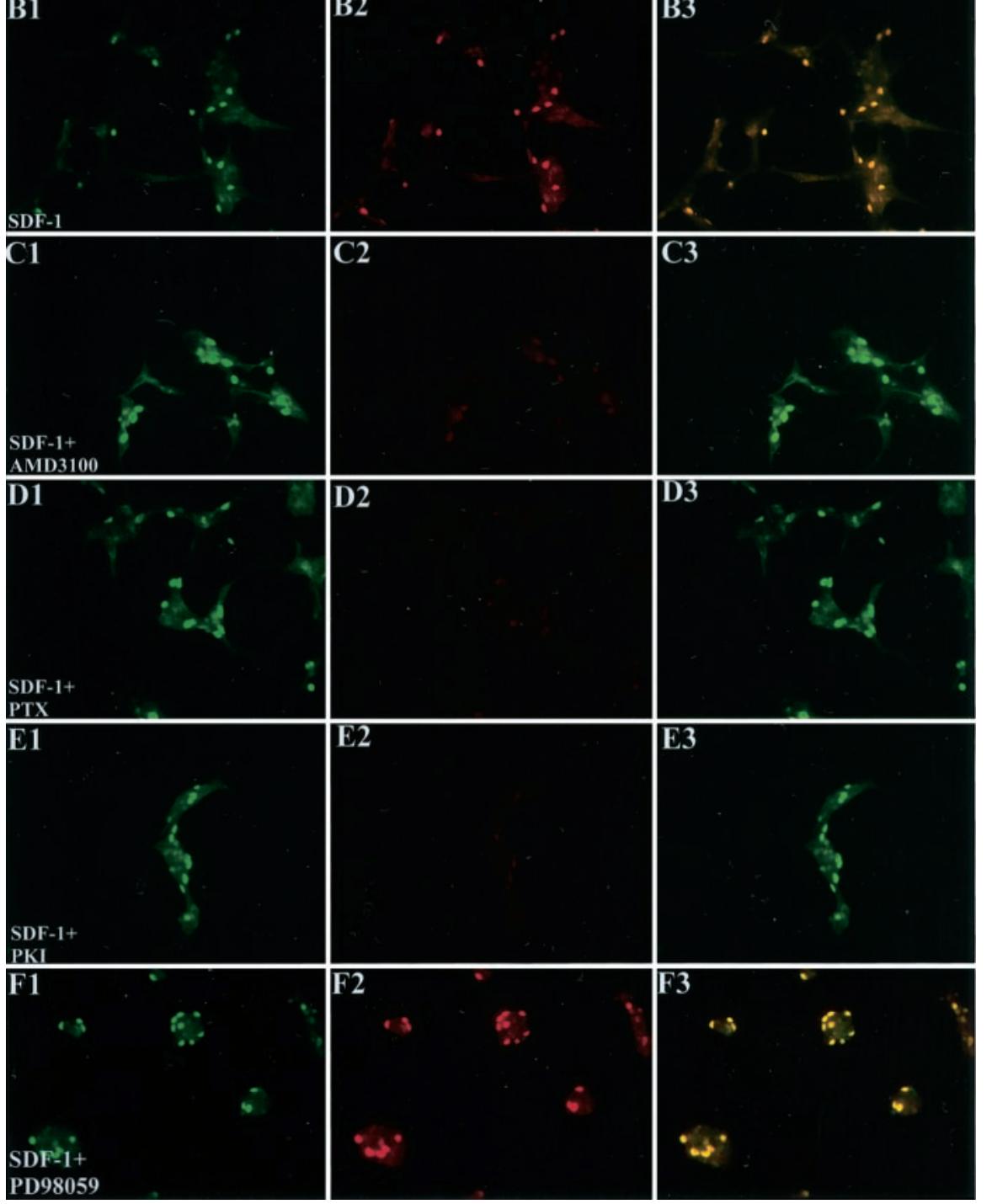

Figure 5. SDF-1 induces phosphorylation and translocation of CREB into the nucleus. E6 retinal neurons were cultured in defined minimal medium for $24 \mathrm{hr}$ (A1-A3) and then exposed to $100 \mathrm{ng} / \mathrm{ml} \mathrm{SDF-1} \mathrm{(B1-B3),} \mathrm{SDF-1} \mathrm{plus} \mathrm{a} 20 \mu \mathrm{m}$ concentration of the CXCR4 antagonist AMD3100 (C1-C3), SDF-1 plus $100 \mathrm{ng} / \mathrm{ml}$ PTX (D1-D3), SDF-1 plus a $200 \mathrm{~nm}$ concentration of the PKA inhibitor PKI (E1-E3), or SDF-1 plus a $20 \mu$ m concentration of MAP kinase inhibitor PD98059 (F1-F3). After $30 \mathrm{~min}$, the cultures were fixed and stained for islet-1 (A1-F1) (green) and phosphorylated CREB (A2-F2) (red). Merged images are shown in A3-F3. SDF-1 induces translocation of phosphorylated CREB into the nuclei of retinal neurons that is blocked by all three pharmacological agents.

brain axons (Li et al., 1999; Nguyen Ba-Charvet et al., 1999; Niclou et al., 2000). It has been shown recently that the chemotaxis of T cells toward a source of SDF-1 in a Boyden chamber assay is reduced in the presence of slit-2 (Wu et al., 2001). Similarly, we find that slit-2 antagonizes the trophic effect of SDF-1 on RGCs. Approximately six collapsing units of slit- 2 reverse the survival-promoting activity of SDF-1 (Fig. 7, compare columns 7 and 11). A collapsing unit is defined as the amount of protein needed to cause $50 \%$ of embryonic chick retinal growth cones to collapse in a collapse assay. The halfmaximal dose for slit-2 reversal of SDF-1 activity is approximately three collapsing units. These results demonstrate that slit-2 reverses the survival-promoting effects of SDF-1 when applied at doses somewhat higher than those required to obtain growth cone collapse.

\section{RGC number is reduced in the CXCR4 knock-out mice}

If SDF-1 promotes neuronal survival through the activation of CXCR4 in vivo, then the absence of CXCR4 should lead to increased neuronal loss during development. To investigate this possibility, the numbers of RGCs in the retinas of wildtype and CXCR4 knock-out embryonic mouse littermates were compared. First, however, we confirmed that SDF-1 promotes the survival of cultured E16.5 mouse RGCs without the addition of any other trophic factors. SDF-1 at $100 \mathrm{ng} / \mathrm{ml}$ increases the proportion of surviving RGCs from $<50$ to $70 \%$ after $24 \mathrm{hr}$ in culture (Fig. $8 A$ ) and from $\sim 10$ to $30 \%$ after $72 \mathrm{hr}$ in culture (Fig. $8 B$ ). CXCR4 mRNA is expressed in the E13.5 mouse RGC layer (Fig. 8C), and SDF-1 is expressed outside the eye in tissues surrounding the optic nerve (Fig. 8 D). Thus, as in chick, CXCR4 is expressed in mouse RGCs, and SDF-1 promotes their survival in vitro.

We used islet-1 as a marker for RGC neurons in the embryonic mouse retina (Erskine et al., 2000). Although islet-1 has been shown to stain both RGCs and displaced amacrine cells at late embryonic ages (E21.5), at the earlier embryonic age used for our analysis it is a specific marker for RGCs (Galli-Resta et al., 1997; Erskine et al., 2000). The numbers of RGCs were compared in wild-type and CXCR4 knock-out littermates. RGCs were counted in thin optical sections $(\sim 2 \mu \mathrm{m})$ made with a confocal microscope from alternate $30 \mu \mathrm{m}$ serial cryostat sections through entire wild-type and mutant eyes. This provides a sample count proportional to the total number of RGCs throughout each eye that does not depend on the precise thickness of individual sections or require correction for nuclei spanning more than one section. A representative reconstruction of a confocal section from an E13.5 wildtype eye is shown in Figure $9 A$. The relative numbers of RGCs were estimated in four mutant and two wild-type eyes from one litter and from two mutant and two wild-type eyes in a second litter (Fig. $9 B$, table). There is an $\sim 35 \%$ reduction in the number of sampled RGCs in CXCR4 mutant compared with wild-type littermates. A parameter-free distribution was assumed, and a Mann-Whitney test was used to estimate that there are 3.2 and $6.1 \%$ chances that there are no differences in RGC numbers be- 
A

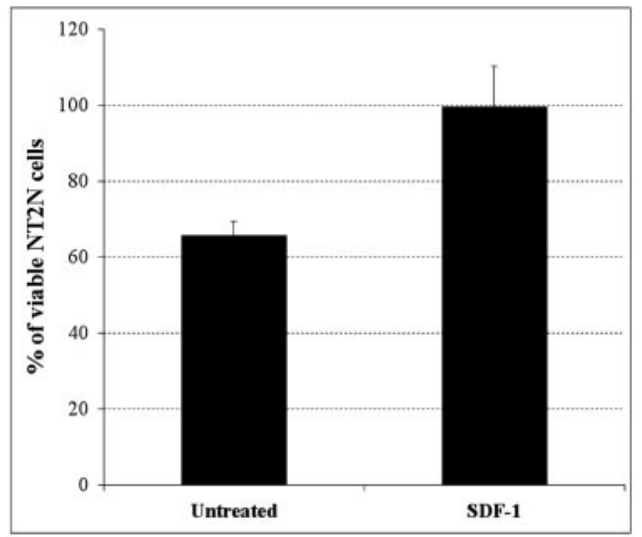

B
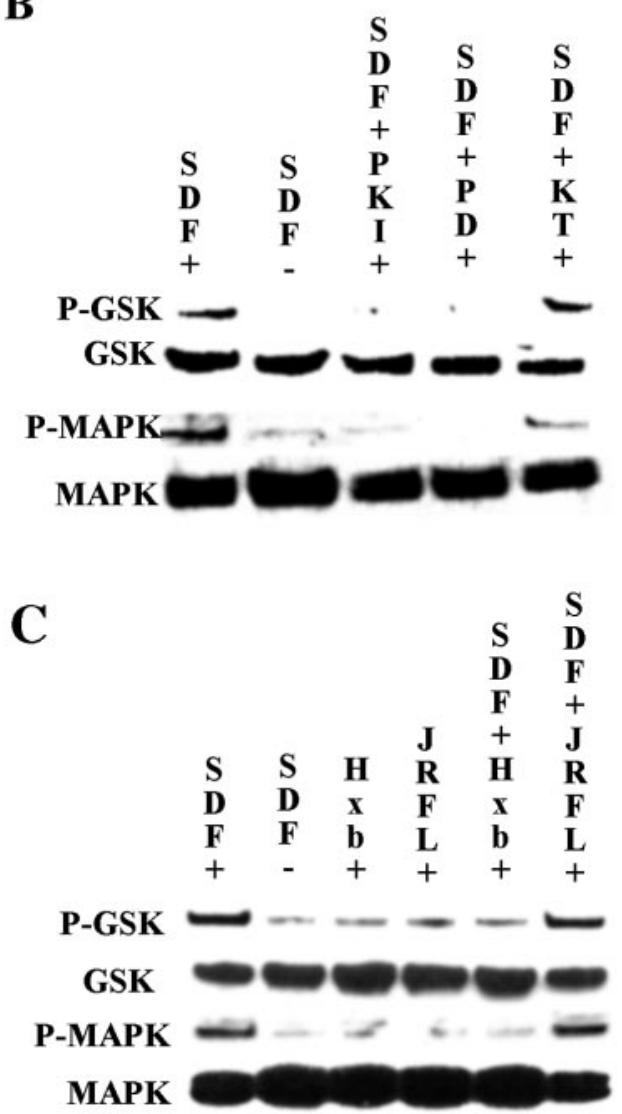

Figure 6. SDF-1 enhances survival and induces phosphorylation of MAP kinase and GSK3 $\beta$ in NT2N cells. A, SDF- $1100 \mathrm{ng} / \mathrm{ml}(p=0.028)$ increases the number of NT2N cells after $24 \mathrm{hr}$ in serum-free medium. $p$ values were calculated by comparing each population with the untreated one using a two-tailed test with different variances. B, SDF-1 enhances phosphorylation of GSK3 $\beta$ and MAP kinase 44/42. The PKA inhibitor PKI at $20 \mu \mathrm{m}$ blocks SDF-1-induced phosphorylation of GSK3 $\beta$ and MAP kinase. The MAP kinase inhibitor PD98059 at $20 \mu \mathrm{m}$ also blocks the phosphorylation of both GSK3 $\beta$ and MAP kinase. The PKG antagonist KT5823 at $1 \mu \mathrm{m}$ does not block SDF-1-induced phosphorylation of GSK3 $\beta$ and MAP kinase. C, Neither $100 \mathrm{ng} / \mathrm{ml}$ HXB-gp120 nor JRFL-gp120 affects GSK3 $\beta$ or MAP kinase phosphorylation on their own. HxBgp120 but not JRFL-gp120 blocks SDF-1-induced phosphorylation of GSK3 $\beta$ and MAP kinase.

tween wild-type and mutant embryos for each of the two litters. The weights of mutant and wild-type embryos were not significantly different from one another (data not shown), nor were the diameters of their eyes (Fig. 9B). Our data show that eyes in E13.5 CXCR4 mutants are of normal size but contain reduced numbers of RGCs. We also compared the number of islet-1/2-positive neurons at E11.5 wild-type and mutant littermates, a time when the first-born RGC neurons begin extending axons in the retina (Young 1985; Cepko et al., 1996). At this early time point, we find no difference in the number of neurons between two knock-outs and four wild-type littermates. These observations are consistent with the hypothesis that SDF-1 helps to promote the survival of RGCs after E11.5; however, they do not eliminate the possibility that RGC production is reduced in CXCR4 mutant embryos.

\section{Discussion}

Neuronal survival is known to be enhanced in many neuronal types by the elevation of cAMP, but ligands that promote neuronal survival in vivo through this mechanism have been hard to identify. Our results suggest that SDF-1 can promote the survival of RGC neurons through the activation of CXCR4 and the stimulation of a cAMP-mediated signaling pathway. This is the first time that SDF-1 has been proposed to have a neurotrophic role during normal development.

Our results are consistent with the hypothesis that SDF-1 acts directly on RGC neurons. These are the only neurons within the retina that express SDF-1 receptor, CXCR4. Moreover, the survival-promoting effect of SDF-1 does not require the presence of other more traditional neurotrophic factors, nor is it mediated by the src kinases common to neurotrophin actions. However, it is impossible to rule out the possibility that SDF-1 promotes neuronal survival by inducing the synthesis or release of another neurotrophic factor.

That SDF-1 exerts its survival effects through the elevation of cAMP is somewhat unexpected. This survival effect is clearly blocked by PTX, yet PTX-sensitive pathways generally act through a $G_{i}$ intermediary that inhibits adenylate cyclase. However, a PTX-sensitive elevation of cAMP like that seen in the survival-promoting pathway of SDF-1 is not without precedent. For example, the metabotropic glutamate receptor mGluR1 can activate adenylate cyclase through a PTX-sensitive $\mathrm{G}_{\mathrm{i}}$ intermediary (Conn and Pin, 1997). SDF-1 may also activate an additional cGMP-mediated pathway in primary embryonic neurons, because an antagonist of cGMP and an inhibitor of PKG each partially reduce the survival-enhancing effects of SDF-1. Similarly, the chemotactic effect of SDF-1 on T cells is mediated through PTX-sensitive activation of both PKG and PKA (Jinquan et al., 2000), and SDF-1 activates a CAMP-dependent pathway to promote an anti-inflammatory reaction in peripheral blood mononuclear cells (Damas et al., 2002). The cAMP-activated pathway we describe seems to play the predominant role in promoting neuronal survival, whereas a cGMP-mediated pathway appears to be activated in parallel and enhances survival to a lesser extent.

The CXCR4-tropic HIV coat glycoprotein HxB-gp120 has been reported previously to have toxic effects on cultured neurons and NT2N cells (Hesselgesser et al., 1998a; Kaul and Lipton, 1999). HIV isolates that bind CXCR4 are toxic to neurons, whereas those that bind CCR5 appear to be less toxic (Ohagen et al., 1999). It has therefore been argued that HxB-gp120 produced by HIV-infected tissue might have a directly toxic effect on nearby cells in the CNS (Ohagen et al., 1999). This apparent toxic effect of HxB-gp120 is also detected in our studies by its reduction in the survival of RGCs but only when SDF-1 is present in the medium. Recent studies have indicated that Hxb-gp120 can cause toxicity to neurons by two different pathways, a CXCR4dependent PTX-sensitive pathway and a second PTXindependent pathway (Zheng et al., 1999). Our experiments suggest that some of this glycoprotein toxicity could be a result of its 


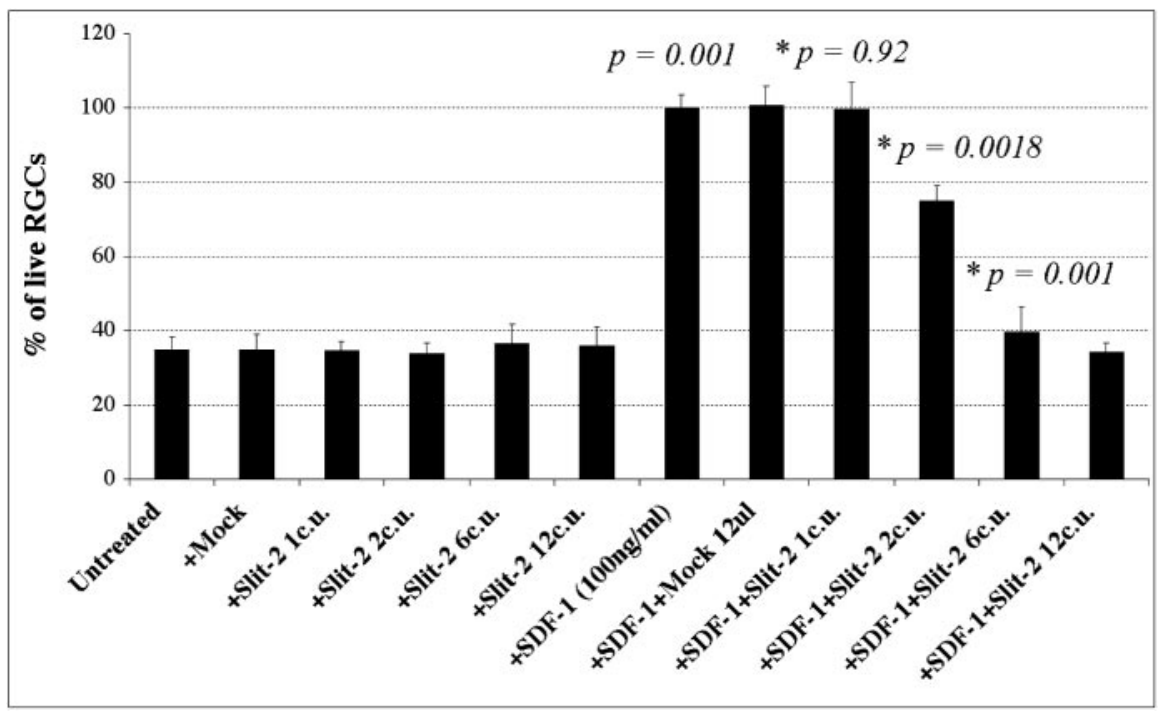

Figure 7. SDF-1-induced survival is blocked by slit-2. Increasing concentrations of slit-2 ( $\geq 6$ collapsing units) can block SDF-1-induced survival. $p$ values were calculated by comparing each population with the untreated one using a two-tailed test with different variances.

A
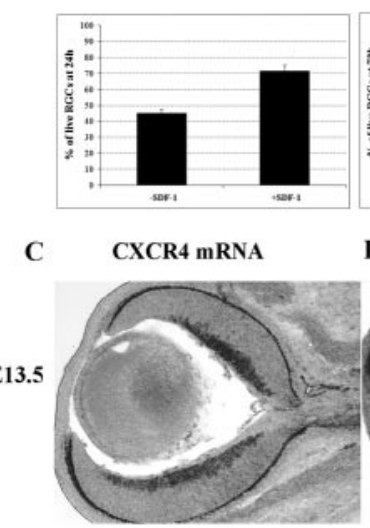

C

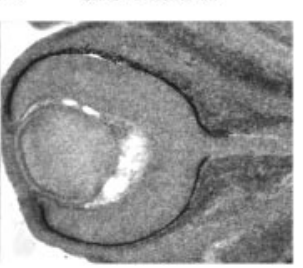

Figure 8. SDF-1 enhances the survival of embryonic mouse RGCs. After $24(A ; p=0.001)$ or $72(B ; p=0.005)$ hr in culture, an increased percentage of RGCs survive in the presence of 100 $\mathrm{ng} / \mathrm{ml}$ SDF-1. $p$ values were calculated by comparing each population with the untreated one using a two-tailed test with different variances. C, CXCR4 mRNA is expressed in the RGC cell layer of E13.5 mouse retina. D, At the same embryonic stage, SDF-1 mRNA is expressed in connective tissues surrounding the eye.

ability to block the binding of SDF-1 to CXCR4 (Staudinger et al., 2001), thereby preventing SDF-1 from activating cAMPmediated survival pathways.

In contrast to our finding that SDF-1 promotes the survival of embryonic chick and mouse RGC neurons, other studies have reported that SDF-1 has neurotoxic effects on E15-E17 rat cerebrocortical cultures (Kaul and Lipton, 1999) and on 13-16 week human fetal neurons (Zheng et al., 1999). One possible explanation for this discrepancy is that different neuron types might behave dissimilarly. For example, SDF-1 might act as a trophic factor early in embryogenesis and have different effects later in development. We have not examined the effects of SDF-1 on older RGC neurons. In at least one instance, SDF-1 has been shown to cause neurotoxicity indirectly via the release of tumor necrosis factor from astrocytes in mixed cultures (Bezzi et al.,
2001). Astrocytes have not yet differentiated in the retinas from which we prepare cultured RGCs (Young, 1985; Cepko et al., 1996). This and the fact that CXCR4 is expressed on only RGCs at these early developmental times may have enabled us to detect a direct trophic effect of SDF-1 on RGC neurons in our cultures. Finally, a recent study has concluded that SDF-1 activates three separate signaling pathways in CD4 T cells, one being a PTX-sensitive prosurvival pathway, whereas another is a competing PTX-insensitive apoptotic pathway (Vlahakis et al., 2002). Our results suggest that in our culture conditions, the PTX-sensitive prosurvival pathway predominates in embryonic RGCs.

Slit-2, a known axonal repellent, has been shown recently to interfere with the chemotactic activity of leukocytes toward SDF-1 (Wu et al., 2001), and here we show that slit-2 also interferes with the survivalpromoting activity of SDF-1 on RGC neurons. Conversely, SDF-1 reduces the efficacy of multiple repellents on several neuronal types (Chalasani et al., 2003). For example, concentrations of SDF-1 that promote RGC survival reduce the sensitivity of RGC axons to slit-2 by $\sim 10$-fold. The first steps of the signaling pathway by which SDF-1 opposes repellent action are identical to those through which it promotes RGC survival. Together, these results suggest that the slit-2- and SDF-1-activated signaling pathways act in opposition to one another. A more general antagonism between survival and axon repellents is hinted at by reports that sema3A can have neurotoxic effects (Fankhauser et al., 1999; Shirvan et al., 1999). We speculate that neurons with misdirected axons that are in contact with repellents for long periods of time may become resistant to survival-promoting signals. This effect, combined with the better known loss of targetspecific trophic signals (Purves et al., 1988; Barde, 1989; Bernstein and Lichtman, 1999), would help remove neurons whose axons were irretrievably lost. Conversely, correctly routed axons with access to target-specific trophic factors may be better able to ignore incidental or weak repellent cues.

The SDF-1 receptor CXCR4 is expressed in a wide variety of neuronal tissues, including RGCs, sympathetic ganglia, dorsal root sensory ganglia, spinal cord, hindbrain, midbrain, olfactory bulb, and the external granule cell layer of the cerebellum (McGrath et al., 1999, and our results). SDF-1 therefore has the potential to enhance neuronal survival among a wide variety of central and peripheral neurons. SDF-1 itself is expressed primarily outside the developing CNS during embryogenesis (McGrath et al., 1999). Thus, embryonic RGCs and other neurons will most often encounter SDF-1 as their axons grow through nonneuronal tissues. Our in vitro results suggest that SDF-1 provides trophic support to embryonic retinal neurons after retinal axons first exit the eye at E11.5 (Young, 1985; Cepko et al., 1996). This expectation is supported by the reduced numbers of E13.5 RGCs in CXCR4 knock-outs compared with wild-type littermates. Other trophic factors such as BDNF, NGF, and CNTF have been shown to promote RGC survival in vitro (Lehwalder et al., 1989; Mansour-Robaey et al., 1994), and it is therefore not surprising that many RGCs persist within the embryo even in the absence of SDF-1/CXCR4 signaling. Unfortunately, it is not practical to de- 


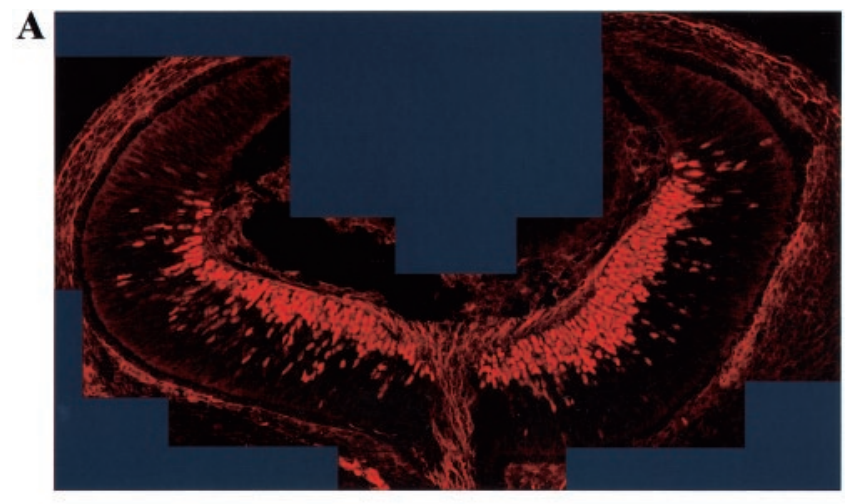

\begin{tabular}{|c|c|c|c|c|c|}
\hline \multicolumn{3}{|c|}{ Litter $1 \varphi=0.032)$} & \multicolumn{3}{|c|}{ Litter $2 \varphi=0.061)$} \\
\hline $\begin{array}{l}\text { No. of } \\
\text { sections }\end{array}$ & $\begin{array}{l}\text { Total RGCs/ } \\
\% \text { control }\end{array}$ & $\begin{array}{l}\text { Estimated } \\
\text { diameter(mm) } \\
/ \% \text { control }\end{array}$ & $\begin{array}{l}\text { No of } \\
\text { sections }\end{array}$ & $\begin{array}{l}\text { Total RGCs/ } \\
\text { \% control }\end{array}$ & $\begin{array}{l}\text { Estimated } \\
\text { diameter (mum) } \\
/ \% \text { control }\end{array}$ \\
\hline Widtype & & & Wildtype & & \\
\hline 9 & $4001 / 100$ & $0.54 / 99$ & 8 & $3148 / 99$ & $0.54 / 96$ \\
\hline 8 & $3950 / 99$ & $0.55 / 100$ & 8 & $3194 / 100$ & $0.58 / 104$ \\
\hline Knockout & & & Knockout & & \\
\hline 9 & $3305 / 83$ & $0.62 / 112$ & 7 & $1823 / 57$ & $0.56 / 100$ \\
\hline 8 & $2743 / 69$ & $0.61 / 110$ & 7 & $1916 / 60$ & $0.53 / 95$ \\
\hline 7 & $2030 / 51$ & $0.60 / 109$ & & & \\
\hline 8 & $2087 / 52$ & $0.55 / 100$ & & & \\
\hline
\end{tabular}

Figure 9. Mice lacking $\mathrm{CXCR} 4$ have fewer $\mathrm{RGCS}$. $A$, Confocal reconstruction of a representative $2 \mu \mathrm{m}$ optical section from an E13.5 wild-type eye. $B$, Table comparing the number of islet-1-positive RGCs (see Materials and Methods) in wild-type and CXCR4 mutant eyes. The number of RGCs in mutant embryos is estimated to be $\sim 65 \%$ of those in wild-type littermates.

termine whether RGC numbers are reduced further over time during late embryonic and postnatal life, because loss of CXCR4 has an embryonic lethal phenotype. This issue can be examined in greater detail when eye-specific conditional knock-outs become available.

It is possible that SDF-1 could provide trophic support to neurons in the mature nervous system. Both CXCR4 and SDF-1 are found in the postnatal CNS (Gabuzda and Wang, 1999; McGrath et al., 1999; Zheng et al., 1999; Tham et al., 2001). SDF-1 is expressed in the cerebellum, olfactory bulb, cortex, dentate gyrus of the hippocampus, and some thalamic nuclei. CXCR4 is widely expressed in CNS neurons, microglia, and astrocytes. Again, it may be possible to determine whether SDF-1 provides trophic support to these cells in mature animals when conditional knock-outs or more potent CXCR4 antagonists become available. There is some evidence to suggest that increased expression of CXCR4 is correlated with neuropathogenesis induced by HIV-1 or by other forms of injury, including trauma and stroke (Gabuzda and Wang, 1999; Klein et al., 1999; Ohagen et al., 1999; Zheng et al., 1999). Moreover, a chemokine like SDF-1 is expected to be expressed in damaged or inflamed tissues (Gonzalo et al., 2000; Evert et al., 2001). We therefore hypothesize that SDF-1 activation of CXCR4 not only provides generalized trophic support to embryonic and mature neurons but also might help support neurons damaged by injury or inflammation.

\section{References}

Alkhatib G, Combadiere C, Broder CC, Feng Y, Kennedy PE, Murphy PM, Berger EA (1996) CC CKR5: a RANTES, MIP- $1 \alpha$, MIP- $1 \beta$ receptor as a fusion cofactor for macrophage-tropic HIV-1. Science 272:1955-1958.

Bagri A, Gurney T, He X, Zou YR, Littman DR, Tessier-Lavigne M, Pleasure SJ (2002) The chemokine SDF1 regulates migration of dentate granule cells. Development 129:4249-4260.
Barde Y-A (1989) Trophic factors and neuronal survival. Neuron 2:1525-1534.

Berger EA, Murphy PM, Farber JM (1999) Chemokine receptors as HIV-1 co-receptors: roles in viral entry, tropism and disease. Annu Rev Immunol 17:657-700.

Bernstein M, Lichtman JW (1999) Axonal atrophy: the retraction reaction. Curr Opin Neurobiol 9:364-370.

Bezzi P, Domercq M, Brambilla L, Galli R, Schols D, De Clercq E, Vescovi A, Bagetta G, Kollias G, Meldolesi J, Volterra A (2001) CXCR4-activated astrocyte glutamate release via TNF $\alpha$ : amplification by microglia triggers neurotoxicity. Nat Neurosci 4:702-710.

Bleul CC, Farzan M, Choe H, Parolin C, Clark-Lewis I, Sodroski J, Springer TA (1996) The lymphocyte chemoattractant SDF-1 is a ligand for LESTR/fusin and blocks HIV-1 entry. Nature 382:829-833.

Cepko CL, Austin CP, Yang X, Alexiades M, Ezzeddine D (1996) Cell fate determination in the vertebrate retina. Proc Natl Acad Sci USA 93:589-595.

Chalasani SH, Sabelko KA, Sunshine MJ, Littman DR, Raper JA (2003) A chemokine, SDF-1, reduces the effectiveness of multiple axon repellants and is required for normal axon pathfinding. J Neurosci 23:1360-1371.

Choe H, Farzan M, Sun Y, Sullivan N, Rollins B, Ponath PD, Wu L, Mackay CR, LaRosa G, Newman W, Gerard N, Gerard C, Sodroski J (1996) The $\beta$-chemokine receptors CCR3 and CCR5 facilitate infection by primary HIV-1 isolates. Cell 85:1135-1148.

Conn PJ, Pin J-P (1997) Pharmacology and functions of metabotropic glutamate receptors. Annu Rev Pharmacol Toxicol 37:205-237.

Coughlan CM, McManus CM, Sharron M, Gao Z, Murphy D, Jaffer S, Choe W, Chen W, Hesselgesser J, Gaylord H, Kalyuzhny A, Lee VM, Wolf B, Doms RW, Kolson DL (2000) Expression of multiple functional chemokine receptors and monocyte chemoattractant protein-1 in human neurons. Neuroscience 97:591-600.

Damas JK, Waehre T, Yndestad A, Ueland T, Muller F, Eiken HG, Holm AM, Halvorsen B, Froland SS, Gullestad L, Aukrust P (2002) Stromal cellderived factor- $1 \alpha$ in unstable angina: potential anti-inflammatory and matrix-stabilizing effects. Circulation 106:36-42.

Doranz BJ, Rucker J, Yi Y, Smyth RJ, Samson M, Peiper SC, Paramentier M, Collman RG, Doms RW (1996) A dual-tropic HIV-1 isolate that uses fusin and the $\beta$-chemokine receptors CKR-5, CKR-3 and CKR-2b as fusion cofactors. Cell 85:1149-1158.

Dragic T, Litwin V, Allaway GP, Martin SR, Huang Y, Nagashima KA, Cayanan C, Maddon PJ, Koup RA, Moore JP, Paxton WA (1996) HIV-1 entry into CD4+ cells is mediated by the chemokine receptor CC-CKR-5. Nature 381:667-673.

Ericson J, Thor S, Edlund T, Jessell TM, Yamada T (1992) Early stages of motor neuron differentiation revealed by expression of homeobox islet-1. Science 256:1555-1560.

Erskine L, Williams SE, Brose K, Kidd T, Rachel RA, Goodman CS, TessierLavigne M, Mason CA (2000) Retinal ganglion cell axon guidance in the mouse optic chiasm: expression and function of Robos and Slits. J Neurosci 20:4975-4982.

Evert BO, Vogt IR, Kindermann C, Ozimek L, de Vos RA, Brunt ER, Schmitt I, Klockgether T, Wullner U (2001) Inflammatory genes are upregulated in expanded ataxin-3-expressing cell lines and spinocerebellar ataxia type 3 brains. J Neurosci 21:5389-5396.

Fankhauser C, Friedlander RM, Gagliardini V (1999) Prevention of nuclear localization of activated caspases correlates with inhibition of apoptosis. Apoptosis 5:117-132.

Feng Y, Broder CJ, Kennedy PE, Berger EA (1996) HIV-1 entry cofactor: functional cDNA cloning of a seven-transmembrane, $G$ protein-coupled receptor. Science 272:872-877.

Gabuzda D, Wang J (1999) Chemokine receptors and virus entry in the central nervous system. J Neurovirol 6:643-658.

Galli-Resta L, Resta G, Tan SS, Reese BE (1997) Mosaics of islet-1expressing amacrine cells assembled by short-range cellular interactions. J Neurosci 17:7831-7838.

Ganju RK, Brubaker SA, Meyer J, Dutt P, Yang Y, Qin S, Newman W, Groopman JE (1998) The $\alpha$-chemokine, stromal cell-derived factor- $1 \alpha$, binds to the transmembrane G-protein-coupled CXCR-4 receptor and activates multiple signal transduction pathways. J Biol Chem 273:23169-23175.

Gerlach LO, Skerlj RT, Bridger GJ, Schwartz TW (2001) Molecular interactions of cyclam and bicyclam non-peptide antagonists with the CXCR4 chemokine receptor. J Biol Chem 276:14153-14160. 
Gonzalo JA, Lloyd CM, Peled A, Delaney T, Coyle AJ, Gutierrez-Ramos JC (2000) Critical involvement of the chemotactic axis CXCR4/stromal cellderived factor- $1 \alpha$ in the inflammatory component of allergic airway disease. J Immunol 165:499-508.

Gonzalez GA, Montminy MR (1989) Cyclic AMP stimulates somatostatin gene transcription by phosphorylation of CREB at serine 133. Cell 59:675-680.

Grewal SS, Fass DM, Yao H, Ellig CL, Goodman RH, Stork PJS (2000) Calcium and cAMP signals differentially regulate cAMP-responsive elementbinding protein function via a RAP1-extracellular signal-regulated kinase pathway. J Biol Chem 275:34433-34441.

Hagiwara M, Brindle P, Harootunian A, Armstrong R, Rivier J, Vale W, Tsien R, Montminy MR (1993) Coupling of hormonal stimulation and transcription via cyclic AMP-responsive factor CREB is rate limited by nuclear entry of protein kinase A. Mol Cell Biol 13:4852-4859.

Halfter W (1998) Disruption of the retinal basal lamina during early embryonic development leads to a retraction of the vitreal end feet, an increased number of ganglion cells and aberrant axonal outgrowth. J Comp Neurol 397:89-104.

Hamburger V, Levi-Montalcini R (1949) Proliferation, differentiation and degeneration in the spinal ganglia of the chick embryo under normal and experimental conditions. J Exp Zool 111:457-502.

Hanson Jr MG, Shen S, Wiemelt AP, McMorris FA, Barres BA (1997) Cyclic AMP elevation is sufficient to promote survival of spinal motor neurons in vitro. J Neurosci 18:7361-7371.

Hartley RS, Margulis M, Fishman PS, Lee VMY, Tang CM (1999) Functional synapses are formed between human Ntera2 (NT2N, hNT) neurons grown on astrocytes. J Comp Neurol 407:1-10.

Hesselgesser J, Halks-Miller M, DelVecchio V, Peiper SC, Hoxie J, Kolson DL, Taub D, Horuk R (1997) CD4-independent association between HIVgp120 and CXCR4: functional chemokine receptors are expressed in human neurons. Curr Biol 7:112-121.

Hesselgesser J, Taub D, Baskar P, Greenberg M, Hoxie J, Kolson DL, Horuk R (1998a) Neuronal apoptosis induced by HIV-1 gp120 and the chemokine SDF- $1 \alpha$ is mediated by the chemokine receptor CXCR4. Curr Biol 8:595-598.

Hesselgesser J, Liang M, Hoxie J, Greenberg M, Brass LF, Orsini MJ, Taub D, Horuk R (1998b) Identification and characterization of the CXCR4 chemokine receptor in human $\mathrm{T}$ cell lines: ligand binding, biological activity and HIV-1 infectivity. J Immunol 160:877-883.

Hu H (1999) Chemorepulsion of neuronal migration by Slit2 in the developing mammalian forebrain. Neuron 23:703-711.

Jinquan T, Quan S, Jacobi HH, Madsen HO, Glue C, Skov PS, Malling HJ, Poulsen LK (2000) CXC chemokine receptor 4 expression and stromal cell-derived factor- $1 \alpha$-induced chemotaxis in $\mathrm{CD}+\mathrm{T}$ lymphocytes are regulated by interleukin-4 and interleukin-10. Immunology 99:402-410.

Kaul M, Lipton SA (1999) Chemokines and activated macrophages in HIV gp120-induced neuronal apoptosis. Proc Natl Acad Sci USA 96:8212-8216.

Klein RS, Williams KC, Alvarez-Hernandez X, Westmoreland S, Force T, Lackner AA, Luster AD (1999) Chemokine receptor expression and signaling in macaque and human fetal neurons and astrocytes: implications for the neuropathogenesis of AIDS. J Immunol 163:1636-1646.

Lee FS, Chao MV (2001) Activation of Trk neurotrophin receptors in the absence of neurotrophins. Proc Natl Acad Sci USA 98:3555-3560.

Lehwalder D, Jeffrey PL, Unsicker K (1989) Survival of purified embryonic chick retinal ganglion cells in the presence of neurotrophic factors. J Neurosci Res 24:329-337.

Li HS, Chen JH, Wu W, Fagaly T, Zhou L, Yuan W, Dupuis S, Jiang ZH, Nash W, Gick C, Ornitz DM, Wu JY, Rao Y (1999) Vertebrate slit, a secreted ligand for the transmembrane protein roundabout, is a repellant for olfactory bulb axons. Cell 96:807-818.

Li M, Wang X, Meintzer MK, Laessig T, Brinbaum MJ, Heidenreich KA (2000) Cyclic AMP promotes neuronal survival by phosphorylation of glycogen synthase kinase 3 3 . Mol Cell Biol 20:9356-9363.

Lu Q, Sun EE, Klein RS, Flanagan JG (2001) Ephrin-B reverse signaling is mediated by a novel PDZ-RGS protein and selectively inhibits $\mathrm{G}$ proteincoupled chemoattraction. Cell 105:69-79.

Luster AD (1998) Mechanisms of disease: chemokines-chemotactic cytokines that mediate inflammation. N Engl J Med 338:436-445.
Luther SA, Cyster JG (2001) Chemokines as regulators of T cell differentiation. Nat Immunol 2:102-107.

Ma Q, Jones D, Borghesani PR, Segal RA, Nagasawa T, Kishimoto T, Bronson RT, Springer TA (1998) Impaired B-lymphopoiesis, myelopoiesis and derailed cerebellar neuron migration in CXCr4-and SDF-1-deficient mice. Proc Natl Acad Sci USA 95:9448-9453.

Mackay CR (2001) Chemokines: immunology's high impact factors. Nat Immunol 2:95-101.

Mansour-Robaey S, Clarke DB, Wang YC, Bray GM, Aguayo AJ (1994) Effects of ocular injury and administration of brain-derived neurotrophic factor on survival and regrowth of axotomized retinal ganglion cells. Proc Natl Acad Sci USA 91:1632-1636.

McGrath KE, Koniski AD, Maltgy KM, McGann JK, Palis J (1999) Embryonic expression and function of chemokine SDF-1 and its receptor, CXCR4. Dev Biol 213:442-456.

Meucci O, Fatatis A, Simen AS, Miller RJ (2000) Expression of $\mathrm{CX}_{3} \mathrm{CR} 1$ chemokine receptors on neurons and their role in neuronal survival. Proc Natl Acad Sci USA 97:8075-8080.

Meyer-Franke A, Wilkinson GA, Kruttgen A, Hu M, Munro E, Hanson MG, Reichardt LF, Barres BA (1998) Depolarization and cAMP elevation rapidly recruit TrkB to the plasma membrane of CNS neurons. Neuron 21:681-693.

Murphy PM, Baggiolini M, Charo IF, Hebert CA, Horuk R, Matsushima K, Miller LH, Oppenheim JJ, Power CA (2000) International Union of Pharmacology. XXII. Nomenclature for chemokine receptors. Pharmacol Rev 52:145-176.

Nagasawa T, Hirota S, Tachibana K, Takakura N, Nishikawa S, Kitamura Y, Yoshida N, Kikutani H, Kishimoto T (1996) Defects of B-cell lymphopoiesis and bone-marrow myelopoiesis in mice lacking the CXC chemokine PBSF/SDF-1. Nature 382:635-638.

Nanki T, Lipsky PE (2000) Cutting edge: stromal cell-derived factor-1 is a co-stimulator for CD4+ T cell activation. J Immunol 164:5010-5014.

Nguyen Ba-Charvet KT, Brose K, Marillat V, Kidd T, Goodman CS, TessierLavigne M, Sotelo C, Chedotal A (1999) Slit-2 mediated chemorepulsion and collapse of developing forebrain axons. Neuron 22:463-473.

Niclou SP, Jia L, Raper JA (2000) Slit2 is a repellant for retinal ganglion cell axons. J Neurosci 20:4962-4974.

Ohagen A, Ghosh S, He J, Huang K, Chen Y, Yuan M, Osathanondh R, Gartner S, Shi B, Shaw G, Gabuzda D (1999) Apoptosis induced by infection of primary brain cultures with diverse human immunodeficiency virus type I isolates: evidence for the role of the envelope. J Virol 73:897-906.

Philips MF, Muir JK, Saatman KE, Raghupathi R, Lee VMY, Trojanowski JQ, McIntosh TK (1999) Survival and integration of transplanted postmitotic human neurons following experimental brain injury in immunocompetent rats. J Neurosurg 90:116-124.

Pleasure SJ, Page C, Lee VMY (1992) Pure, postmitotic polarized human neurons derived from NTera2N cells provide a system for expressing exogenous proteins in differentiated neurons. J Neurosci 12: 1802-1815.

Purves D, Snider WD, Voyvodic JT (1988) Trophic regulation of nerve cell morphology and innervation in the autonomic nervous system. Nature 336:123-128.

Raff M (1998) Cell suicide for beginners. Nature 396:119-122.

Rydel RE, Greene LA (1988) cAMP analogs promote survival and neurite outgrowth in cultures of rat sympathetic and sensory neurons independently of NGF. Proc Natl Acad Sci USA 85:1257-1261.

Shen S, Wiemelt AP, McMorris FA, Barres BA (1999) Retinal ganglion cells lose trophic responsiveness after axotomy. Neuron 23:285-295.

Shirvan A, Ziv I, Fleminger G, Shina R, He Z, Brudo I, Melamed E, Barzilai A (1999) Semaphorins as mediators of neuronal apoptosis. J Neurochem 73:961-971.

Staudinger R, Wang X, Brandés JC (2001) HIV-1 envelope is a neutral antagonist to CXCR4 in $\mathrm{T}$ cells. Biochem Biophys Res Commun 280:1003-1007.

Tachibana K, Hirota S, Lizasa H, Yoshida H, Kawabata K, Kataoka Y, Kitamura Y, Matsishima K, Yoshida N, Nishikawa S, Kishimoto T, Nagasawa $\mathrm{T}$ (1998) The chemokine receptor CXCR4 is essential for the vascularization of the gastrointestinal tract. Nature 393:591-594.

Tham TN, Lazarini F, Franceschini IA, Amara A, Dubois-Dalcq M (2001) 
Developmental pattern of expression of the $\alpha$ chemokine stromal cellderived factor 1 in the rat central nervous system. Eur J Neurosci 13:845-856.

Vlahakis SR, Villasis-Keever A, Gomez T, Vanegas M, Vlahakis N, Paya CV (2002) G protein-coupled chemokine receptors induce both survival and apoptotic signaling pathways. J Immunol 169:5546-5554.

Wakade AR, Edgar D, Thoenen H (1983) Both nerve growth factor and high $\mathrm{K}^{+}$concentrations support survival of chick embryo sympathetic neurons. Exp Cell Res 144:377-384.

Wang KH, Brose K, Arnott D, Kidd T, Goodman CS, Henzel W, TessierLavigne M (1996) Biochemical purification of a mammalian slit protein as a positive regulator of sensory axon elongation and branching. Cell 96:771-784.
Wu JY, Feng L, Park HT, Havlioglu N, Wen L, Tang H, Bacon KB, Jiang ZH, Zhang XC, Rao Y (2001) The neuronal repellant Slit inhibits leukocyte chemotaxis induced by chemotactic factors. Nature 410:948 -952.

Young RW (1985) Cell differentiation in the retina of the mouse. Anat Rec 212:199-205.

Zheng J, Thylin MR, Ghorpade A, Xiong H, Persidsky Y, Cotter R, Niemann D, Che M, Zeng Y, Gelbard HA, Shepard RB, Swartz JM, Gendelman HE (1999) Intracellular CXCR4 signaling, neuronal apoptosis and neuropathogenic mechanisms of HIV-1 associated dementia. J Neuroimmunol 98:185-200.

Zou Y, Kottmann AH, Kuroda M, Taniuchi I, Littman DR (1998) Function of the chemokine receptor CXCR4 in haematopoiesis and in cerebellar development. Nature 393:595-599. 